\title{
Building a healthier community: Kalisz as the city of healthy families
}

\author{
Kinga Janik-Koncewicz \\ Health Promotion Foundation, Nadarzyn, Poland
}

ADDRESS FOR CORRESPONDENCE: Kinga Janik-Koncewicz, Health Promotion Foundation, 51 Mszczonowska St., 05-830 Nadarzyn, Poland, e-mail: biuro@promocjazdrowia.pl

Supplementary materials (slides) are available in Webappendix 14 at the journal's website: https://www.termedia.pl/Journal/Journal_of_ Health_Inequalities-100.

The third session of the Calisia World Conference on Family Health was devoted to the theme of building healthier communities. Its aim was to share international examples of best practices, and to suggest initiatives that could be implemented to improve the health and wellbeing in the Kalisz region. The population of the city of Kalisz is around 100,000 people. Sixty per cent of the city inhabitants are aged 20-64 years. Several prevention programmes and health promotion activities are provided by the local authority. They are focused on early detection of breast cancer in women in the high-risk 40-49 age group, vaccination against flu in the population aged 60 and above, and vaccination against human papilloma virus (HPV) in the cohort of girls born in 2006 [1].

In order to plan any effective interventions, it is necessary to first evaluate the current health status of the population. The Kalisz region (consisting of seven counties and the city of Kalisz) in 2017 had a population of 327,000 men and 344,000 women. In the same year 1257 adult men and 506 women died prematurely in this region. The all-cause mortality rate was $595 / 100,000$ for men and 242/100,000 for women. This means that in the Kalisz region, $34 \%$ of deaths in men and $16 \%$ in women occurred in the 20-64 age group. Cancer was the leading cause of adult premature mortality; however, it was more dominant in women ( $29 \%$ in men, $46 \%$ in women). The second cause was diseases of the circulatory system $(19 \%$ in men, $17 \%$ in women) [2].

New York (NYC) is a city of 8.5 million residents, in which several effective prevention strategies were introduced by the city's Department of Health and
Mental Hygiene [3]. The NYC experiences could provide a good example for Kalisz. A key consideration underpinning these strategies should be an environment conducive to good health. While individuals are responsible for their own health and should be helped with developing the necessary competences to take care of it, it is vital to understand that the environment in which they live can often determine their access to healthy choices. It is the responsibility of local authorities to foster an environment that empowers inhabitants to protect their health. In NYC, after salt added to food consumed outside homes was identified as the main source of sodium intake, the city introduced a programme that helped convince food manufacturers to decrease the content of sodium in their products [3].

There are also several effective Polish health promotion programmes that could be implemented in the Kalisz region. One of them is the educational programme "I choose", dedicated to the improvement of health literacy and health-related competences in the population of Lower Silesia [4]. New digital technologies supporting medical doctors and smokers in the treatment of tobacco dependence are also being developed [5]. Finally, there are effective programmes that have been provided in the region for years, such as the cervical cancer prevention programme [6], which need to be continued.

Key words: healthy community, prevention programmes, healthy environment, health promotion programmes.

\section{DISCLOSURE}

The author reports no conflict of interest. 


\section{References}

1. Kinastowski K. Summary of Mayor Krysian Kinastowski’s presentation at the Calisia World Conference on Family Health. J Health Inequal 2019; 5: 47.

2. Database of demography. National Statistical Office. Available from: http://demografia.stat.gov.pl/bazademografia/ (accessed: 15 May 2019).

3. Angell SY. Generating health in New York City. J Health Inequal 2019; 5: 48.

4. Janik-Koncewicz, Rosik K, Młoźniak I, et al. Public health students as health educators: health awereness and behaviours among primary care professionals and public health students conducting a health literacy intervention. J Health Inequal 2019; 5: 89-95.

5. Herbeć $\mathrm{O}$. The future of treatment of tobacco dependence - harnessing technology to deliver hybrid interventions. J Health Inequal 2019; 5: 49.

6. Stelmach M. Cervical cancer - still a serious problem for public health in Poland. What is needed to solve it? J Health Inequal 2019; 5: 50 . 